\author{
外山茂樹・飴野貴 明 \\ 十 亀 盛 男
}

名古屋大学工学部 化学工学科*

\begin{abstract}
邪魔板なし攪汼槽内でのバルク液の乱流消散エネルギーを熱線流速計を用いて測定した．測定法 を検討し攪拌槽では乱流変動の微分信号から算出する方法が, 従来から行われているエネルギース ペクトル法より妥当であり，またプローブの挿入方向も，水平鉛直方向が適切である結果を得た。

測定された消散エネルギーは位置による差異が大きく最大数十倍に達するが，各位置での消散エ ネルギーは所要動力に比例し，分布形状は回転数によらないことを確かめた。 またバルク液乱流消 散エネルギーの合計は, 所要動力の約 2 割弱にしかならない結果を得た.

この結果は吐出流の主流ベクトル変動によるレイノルズ応力を考慮して解いた運動方程式からの エネルギー収支と一致した。また壁面境界層の粘性消散エネルギーを計算するとバルク液乱流消散 エネルギーと同程度である結果を得た。
\end{abstract}

\section{緒言}

消散エネルギーは, 局所的には気液および液々の分散 過程や熱拉よび物質の移動現象に重要な影響を与える流 れ構造の因子であり, 攪拌槽全体として見れば攪拌所要 動力と直接関係するものである.

このため多くの摫拌操作が単位体積あたりの所要動力 を消散エネルギーとみなし, 相関されてきたが, 最近測 定方法の進歩によって直接消散エネルギーを測定した研 究報告 $2,3,7,0,10)$ が見られるようになってきた。

攪拌槽内は, よく知られているょうに，一様な完全混 合ではなく,場所により流動状態が異なり,消散エネルギ 一も場所により数十倍も違うことが報告されている ${ }^{9}$. その上，攪找翼によって槽内に与兄られた動力が全てバ ルク液の乱流消散エネルギーとして消費されるかどらか に対しても諸説 $2,3,8)$ ある.

本研究は邪魔板なし攪汼槽に括ける乱流変動を熱線流 速計を用いて測定し, 出力を種々の方法で処理し乱流消 散エネルギー分布, および所要動力と消散エネルギーの 関係を求め, 同時に消散エネルギーの測定法に対する検 討をした. 一方槽内流速分布と運動方程式を用い, 所要 動力とバルク液内消散ェネルギーの関係を求めた。 その 結果新しい知見が得られたのでここに報告する.

\section{1. 実験装置および方法}

\section{$1 \cdot 1$ 実験装置とその設定}

実験に用いた攪拌槽は Fig. 1 に示すように内径 585 $\mathrm{mm}$ のアクリル製円筒槽で, 水深は内径に等しくした. 攪拌翼はパドル型で, 径 $d=D / 2$, 幅 $b=d / 5$ の 6 枚羽 * F464 名古屋市千種区不老町
根と 8 枚羽根の 2 種類を用いた. 攪找レイノルズ数は完 全発達乱流攪拌の範囲で $60 \times 10^{3}$ と $120 \times 10^{3}$ の 2 点に ついて行った.

所要動力および軸トルクは観拌軸にひずみ抵抗トルク 計を取り付け測定した. 流速測定は熱線流速計を用い, 熱線プローブは Thermo-System 社の $1211 \mathrm{~W}$ 型を用 いた. このプローブは線径 $a=20 \mu \mathrm{m}$, 線長 $l=1.0 \mathrm{~mm}$ であり, Fig. 2 に示すようにプローブの延長方向が支持 棒と同軸となっている.

攪拌槽内流動は 3 次元的であり，その上主流ベクトル は翼近くの吐出流でたえず方向を变えている. 一方上に 示した熱線プローブの長さ $l$ と径 $a$ の比は約 50 と小 さく，熱線に直交しない流れに対して余弦法則からのず れが大きく1) 出力の信頼性が小さい.このため水素気泡 法と,アルミ箔をトレーサーに用いた光切断法によって 槽内の主流ベクトルの方向を観察した.

可視化の結果から槽内主流ベクトルは, ほとんど水平 面に平行の 2 次元流であった. 翼近傍の吐出流ベクトル は絶えず方向を変動しているが，乙かし水平面内変動で あった，そこで Fig. 2 に示すように熱線の方向を鉛直 に保って槽内に插入し，主流が常に熱線に直交するよう にして余弦法則からのずれを考虑しなくてすむようにし た.

完全発達乱流攪挥では乱流レイノルズ数が非常に大き く, 本実験の二つの㩭找レイノルズ数に対応して, 吐出 流域でそれぞれ $R e_{\lambda}=400,800$ であった。 また消散渦ス ケールは約 $3 \mathrm{~mm}$ と小さかったので, 波数空間の消散渦 スケール近傍で局所等方性を仮定した.

測定に用いた回転構成を Fig. 3 にブロック線図で示 す. エネルギー分布は一度出力を磁気テープに記録し, 


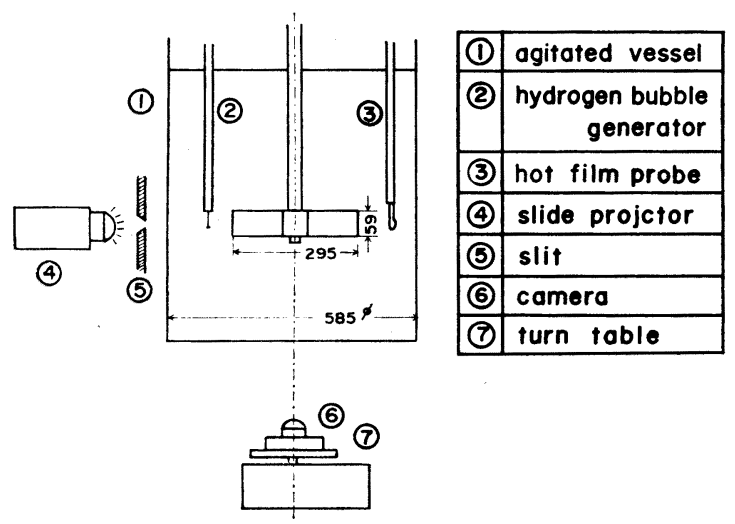

Fig. 1 Schemetic diagram of experimental apparatus

狄带域滤波器に繰り返し通し積分して求めた。 また同時 に自己相関関数をフーリエ変換することによっても求 め, お㧍上その一致を見た. 速度変動の時間微分 $\partial u / \partial t$ の強度は一度低域濾波器で高周波成分を取り除き，その 後, 微分回路を通し, その出力を R.M.S. 計を通して求 めた。作成した微分回路は正弦波で $1,000 \mathrm{~Hz}$ まで直線 性のあることと確認して用いた。低域濾波器の遮断周波 数は $1,000 \mathrm{~Hz}$ に設定し*, これ以上高周波の乱流変動は 液中では無視できるとして信号対雑音比を向上させた。 零値通過回数は, 乱流変動出力を高域滤波器を通し, 低 周波分を取り除き，周波数カウンターで求めた．高域慮 波器の遮断周波数は攪拌翼が熱線プローブを通過する周 波数の 2 倍とした**.なお用いた 3 種の滤波器の遮断特 性は共に $18 \mathrm{~dB} /$ oct である.

\section{1 ・2 消散エネルギー計算法}

等方性乱流を仮定すれば消散エネルギーを求める方法 は次の 4 種の方法があり ネルギーを求め比較検討した。

1. コルモゴロフ・スペクトルを利用する方法

等方性乱流にさらに慣性小領域の存在を仮定する と,この範囲で

$$
E(k)=C \varepsilon^{2 / 3} k^{-5 / 3}
$$

* 本実験条験では, $1,000 \mathrm{~Hz}$ は場所により $k=50 \sim 100[1 / \mathrm{cm}] の$ 波数に対応する.これに対応する渦スケールは，1.0 0.5 mm で

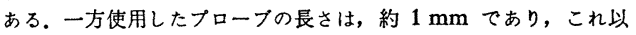
下の渦に対してプローブの応答は急激に減衰する。また消散スケー

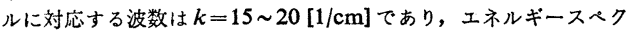
トルから見ても,$k=50 \sim 100[1 / \mathrm{cm}]$ のあたりのエネルギーは $k=$ $15 \sim 20[1 / \mathrm{cm}]$ のエネルギーに比へ無視できるほど小さい.

以上二つの理由により， $S / N$ 比を上げるため低域汇波器の遮断

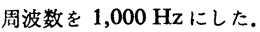

** 消散エネルギーに寄与する周波数は本実験範囲では $200 \sim 300 \mathrm{~Hz}$ である。吐出流部では吐出流の低周波のコヒーレントモーションと 消散に寄与寸る乱れも重冨しているわけであり，この吐出流のコヒ ーレントモーションを遮断して, 消散エネルギーに寄与する乱れの 乱流信号による零值通過回数を求めた。

なお本実験条件での吐出流変動周波数は約 $10 \mathrm{~Hz}$ で相当する波 数は $0.5 \sim 1.0[1 / \mathrm{cm}]$ である。
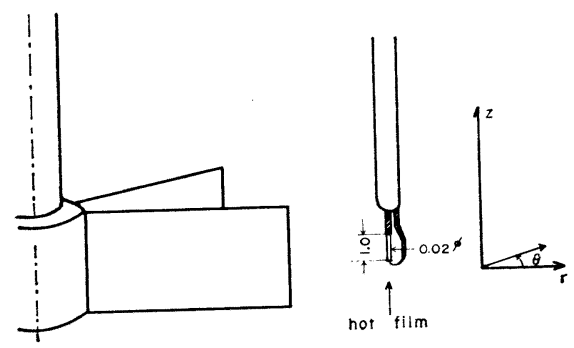

Fig. 2 Relative direction of hot film probe to impeller

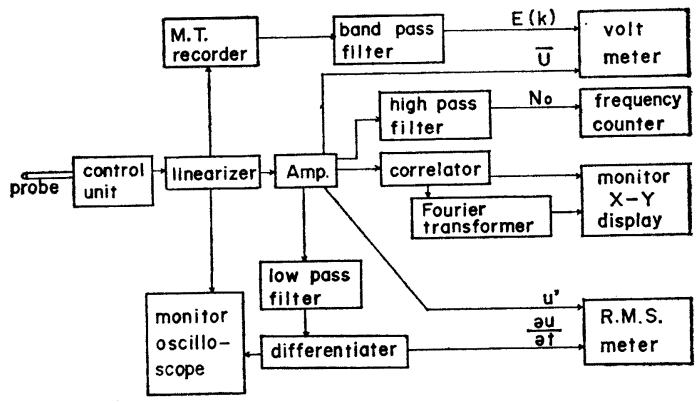

Fig. 3 Brock diagram of signal processing system

が成立し，この領域が存在する範囲で $E(k)$ を求 め $\varepsilon$ を計算する.

2. エネルギースペクトルの積分から求める方法

$$
\varepsilon=15 \gamma \int k_{1}{ }^{2} E_{1}\left(k_{1}\right) d k_{1}
$$

3. 微分信号から求める方法

$$
\varepsilon=30 \gamma \frac{u^{\prime 2}}{\lambda_{f}{ }^{2}}, \quad \frac{1}{\lambda_{f}{ }^{2}}=\frac{1}{2 u^{\prime 2}} \overline{\left(\frac{\partial u}{\partial x}\right)^{2}}
$$

ここでは Taylor の凍結仮定を用い Eq. (3) の 消散スケール $\lambda_{f}$ を次式で求めた。

$$
\frac{1}{\lambda_{f}^{2}}=\frac{1}{2 u^{\prime 2}} \cdot \frac{1}{U^{2}} \overline{\left(\frac{\partial u}{\partial t}\right)^{2}}
$$

4. 零值通過回数法

乱流変動の $u$ と $\partial u / \partial t$ がガウス分布すれば Eq. (3) に打ける消散スケール $\bar{\lambda}_{f}$ は次式で求められ る.

$$
\frac{1}{\lambda_{f}}=\frac{\pi N_{0}}{\sqrt{2 U}}
$$

穓抖槽内乱流は非等方で乱流変動の出現確率も歪 んでいるため前述のように高域滤波器を通し, 非 等方の低周波傾変動を取り除き消散に寄与する高 周波変動の零値通過回数だけを求めた.

\section{2. 実験 結 果}

Fig. 4 は吐出流域で 1 点から水素気泡を発生させ，そ の流脈を長時間露光で写したものである．これは変動す る吐出流の重㸚合わせであり, 吐出流ベクトルはこの範 囲を変動していることを示す。この変動の広がり角は約 


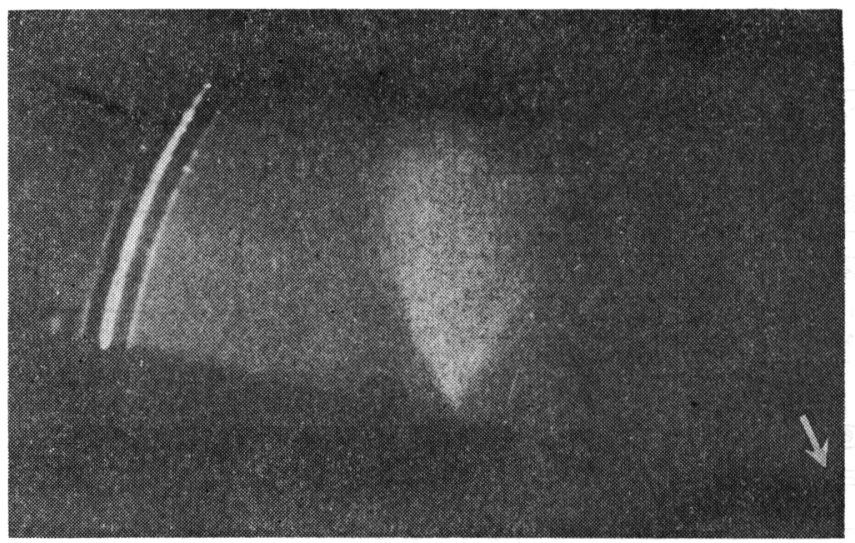

Fig. 4 Superposition of pass lines of fluctuated main flow vector in the discharge flow visualized by hydrogen bubble, impeller rotating velocity $80 \mathrm{rpm}$, exposure time 5 minute, arrow indicating the center of the vessel

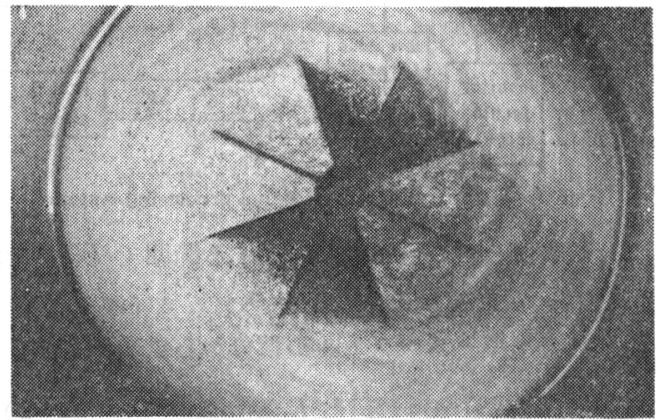

Fig. 5 Light cut photograph at discharge flow plane visualized by Alminum tracer viewing from camera rotating at a same speed to the impeller

$60^{\circ}$ であった. しかし横方向から見た鉛直方向の広がり 角は約 $5^{\circ}$ であった．このベクトルの方向変動も乱流と 見るならば，水平方向の乱流変動は鉛直方向に比べ非常 に大きく，乱れは非等方である. また水平方向変動が大 きいため，水平に置か玌た熱線プローブは余弦の法則か らのずれが少なくない。

Fig. 5 は翼内流動および㕵出流をアルミ䇴トレーサー で観察したものである。これはFig. 1 に示したように㩭 拌軸延長上に攪拌翼回転に同期した回転円板を設置し, その上にカメラを乗せ光切断で観察したものである. 㩭 汼翼端から渦の放出される様子が見られ，また吐出流の 周方向成分が翼先端速度より遅れているのが観察され る. この事実は, 後に述べるように, 翼から槽内に放出 されるェネルギーが軸動力に比べ非常に小さいことと関 連している。

微分信号から求める方法で測定された槽内消散ェネル ギー分布の一例を Fig. 6 に示す。図から見られるよら に消散エネルギーは吐出流域で最大で, 循環流に沿って 次第に減少していく，消散エネルギーは翼上下の固体的 回転部で最少となり, 吐出流域とでは数十倍の違いがあ

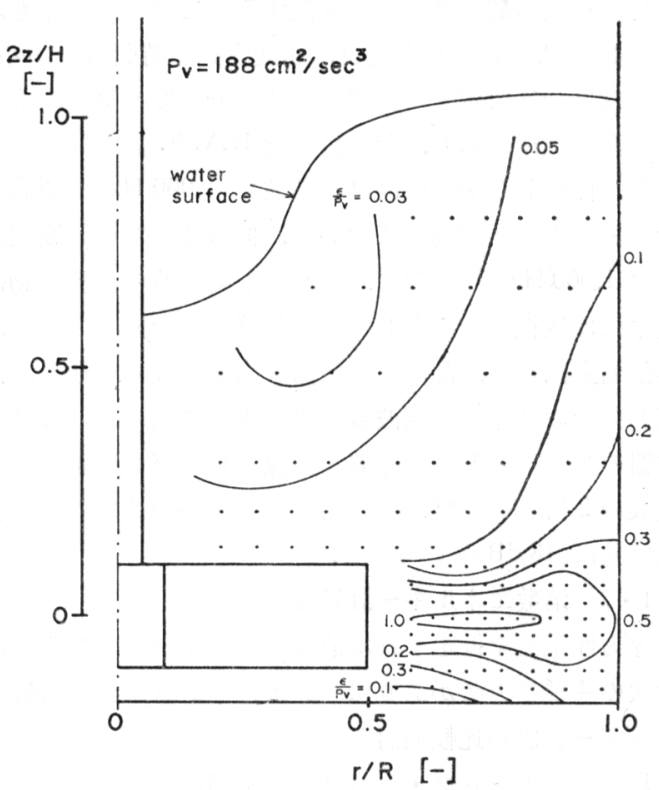

Fig. 6 Contour map of turbulent dissipation energy at $80 \mathrm{rpm}\left(\operatorname{Re}=1.2 \times 10 \mathrm{e}, N_{P}=0.59\right)$

る、しかし各位置での消散エネルギーは完全乱流攪拌の 範囲で所要動力に比例し, 分布形状は回転数を変觉ても 著しい変化はなかった。な脑図中に示した多くの黒点は 測定点を示す.

この消散エネルギー分布を軸対称と考克, 槽全体にわ たって積分すると, 所要動力の約 2 割弱しかならず, 所 要動力の一部しか, バルク液乱流エネルギーとして消散 していないことを示している.

攪汼翼を 8 枚羽根から 6 枚羽根に取り換觉ても消散エ ネルギー分布には著しい変化はなく， 6 枚羽根の方が吐 出流の水平方向変動がわずかに広がったのが見られただ けであった。 


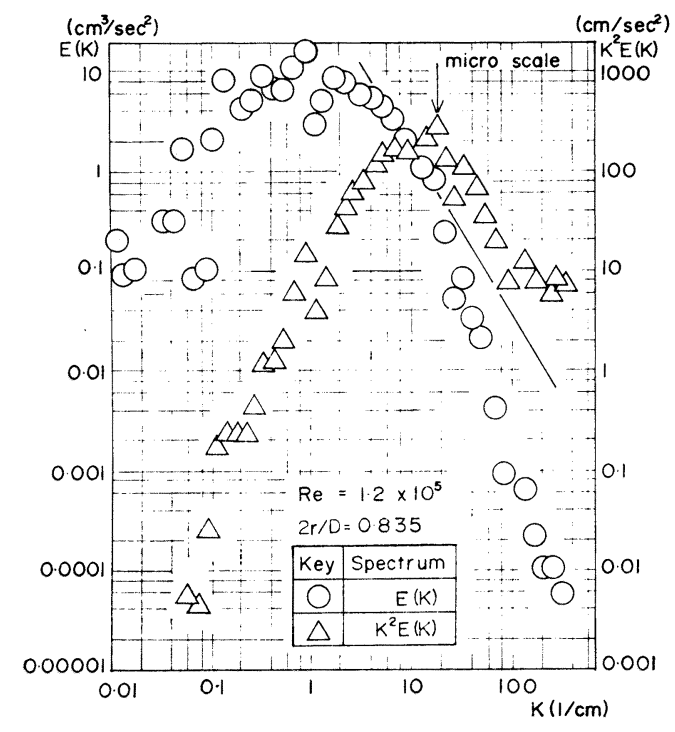

Fig. 7 An example of typical energy spectrum and dissipation energy spectrum at 80 r.p.m. $(R e=$ $1.2 \times 10^{5}, N_{P}=0.59$ )

Arrow indicates the wave number corresponding to micro scale

\section{3. 考察}

\section{3・1 実験法の考察}

等方性乱流では，Eq. (2) 拉よび Eq. (3) の消散エネ ルギーの求め方は理論的に同じものである. しかし測定 精度の問題から, 二つの方法は特に摫拌槽のような非等 方性乱流では異なった值を提供する。

Fig. 7 に $z=0, r / d=0.835$ のエネルギースペクトル と消散エネルギースペクトルを示す。をた図中矢印は微 分法で求めた消散スケールに対応する波数を示してい る、消散エネルギースペクトルのピークの波数と微分信 号から求めた消散スケールに対応する波数が一致してい ることは注目に値する。このためこの二つの計算法は局 所消散エネルギー測定に対してもよい一致をしているよ らに見えるが，（2）の方法は高周波側の積分が重要であ るのに，そのスペクトルが低周波側に比べ著しく小さ く，高周波側信号レベルが雑音と同程度となり，スペク トル強度の值の信頼性が小さい，著者らの用いた磁気テ 一プ記録計は $S / N$ 比が $42 \mathrm{~dB}$ であり，また相関計の $\mathrm{AD}$ 变換も 8 ビットであり, 共に 2 ケタの修頼性しかなく, したがって Fig. 7 において $k>50$ のスペクトルの值 に対しては信頼性がない。

そこで，あるスペクトル関数を仮定して低周波のエネ ルギースペクトルを高周波側へ外挿する方法がよく使用 されるが，攪拌槽内流動のような複雑な 3 次元流動では 低周波側スペクトル測定は熱線流速計では困難であり， 外挿される高周波側スペクトルは真の值を離れ，低周波

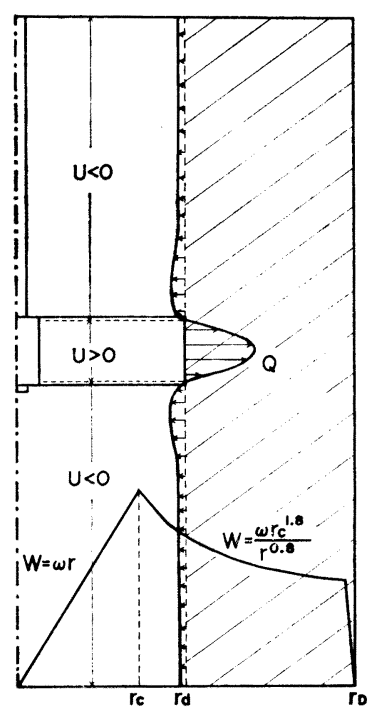

Fig. 8 Schematic diagram of subdivided vessel into double cylinder

スペクトル測定に依存したものとなる。

計算法 1，および 2, は理論的には異なった方法であ るがスペクトルから求めることで実験手段としては同一 であり，消散エネルギーの計算值もよい一致をした．翼 から離れた所で等方性乱流の仮定が妥当と思われるあた りは 1,2,3 の方法で求めた值は共に非常に小さい值で沙 り互によい一致を示した。しかし翼近傍の吐出流域では Table 1 に示すようにスペクトルで求めた值が微分から 求めた值の約 10 倍も大きく，吐出面内での半径方向の 変化が微分から求めたものに比べ非常に大きい。この值 を用いると所要動力のほとんどがバルク液で消散されて いることになる甲．しかしこれは先に示した非等方性乱 流でのスペクトル湘定の信頼性欠除のため，大きな值に なったものと推察される．また後に示すように運動方程 式から導かれるエネルギーバランスからも，バルク内消 散エネルギーは所要動力に比べ小さく，エネルギースペ クトルから消散エネルギーを求める方法は疑問がある. ここでは乱流信号の直接微分から求めの方法 Eq. (3)を 採用した．微分回路は本質的に高域濾波器であるので非 等方性乱流の低周波は自動的に落され，消散エネルギー に寄与する高周波の $S / N$ 比を向上させているものと推 察される。

Eq. (4) で求めた消散スケールは Eq. (3) で求めた值 とよい一致を示した．高域濾波器は翼通過周期から出て くる低周波の非等方成分を取り除くためで，この高周波 振動の乱流強度出現確率密度はガウス型に近いものが得 られた。

同一測定法で完全邪魔板条件靦汼の消散エネルギーを 測定した結果，所要動力の約 5 割であった．完全邪魔板 
Table 1 Comparison of the results from two different calculating methods for turbulent dissipation energy

\begin{tabular}{|c|c|c|c|c|c|c|c|c|c|c|}
\hline \multirow[b]{3}{*}{$2 r / D$} & \multicolumn{6}{|c|}{$\begin{array}{c}80 \mathrm{rpm} P_{v}=188 \mathrm{~cm}^{2} / \mathrm{s}^{3} \\
\left(N_{P}=0.59\right)\end{array}$} & \multicolumn{4}{|c|}{$30 \mathrm{rpm} P_{\left(N_{P}=0.78\right)}=10.9 \mathrm{~cm}^{2} / \mathrm{s}^{3}$} \\
\hline & \multicolumn{2}{|c|}{$2 z / H=0$} & \multicolumn{2}{|c|}{$2 z / H=0.48$} & \multicolumn{2}{|c|}{$2 z / H=0.80$} & \multicolumn{2}{|c|}{$2 z / H=0$} & \multicolumn{2}{|c|}{$2 z / H=0.035$} \\
\hline & $\varepsilon^{\prime} / P_{v}$ & $\varepsilon / P_{v}$ & $\varepsilon^{\prime} \mid P_{v}$ & $\varepsilon / P_{v}$ & $\varepsilon^{\prime} \mid P_{v}$ & $\varepsilon / P_{v}$ & $\varepsilon^{\prime} / P_{v}$ & $\varepsilon / P_{v}$ & $\varepsilon^{\prime} \mid P_{v}$ & $\varepsilon / P_{v}$ \\
\hline 0.21 & & & 0.07 & 0.04 & & & & & & \\
\hline 0.54 & & & & & & & 4.11 & 1.65 & 2.11 & 1.56 \\
\hline 0.56 & 5.68 & 0.77 & & & 0.01 & 0.05 & & 1.76 & & \\
\hline 0.58 & & & & & & & & & 3.00 & 1.18 \\
\hline 0.59 & & 0.99 & & & & & & 2.18 & & \\
\hline 0.62 & 6.53 & 0.85 & 0.02 & 0.05 & & 0.03 & & & & 1.27 \\
\hline 0.69 & & & & & & 0.04 & 2.11 & 2.54 & & 1.57 \\
\hline 0.70 & 6.53 & 1.11 & & 0.07 & & & & 1.90 & & \\
\hline 0.75 & & 1.02 & & & & 0.05 & 1.41 & 1.78 & & 1.91 \\
\hline 0.77 & 3.01 & 1.20 & & 0.09 & & & & 1.51 & & 1.72 \\
\hline 0.83 & 1.68 & 0.90 & & & & 0.06 & & 0.58 & & 1.01 \\
\hline 0.90 & & 0.95 & 0.15 & 0.10 & 0.02 & 0.06 & & 0.46 & & 0.55 \\
\hline 0.97 & 0.61 & 0.61 & & & & 0.06 & & & & \\
\hline$\varepsilon^{\prime}$ is & ted fror & $\begin{array}{l}\text { gy spe } \\
\text { entiate }\end{array}$ & & & & & & & & \\
\hline
\end{tabular}

条件では主流が定まらず熱線流速計による測定は信頼性 に乏しいが，邪魔板の設置位置間の二等分断面で測定 し，そのまま軸対称として積分した．邪魔板近傍はさら に大きな消散エネルギーになると推定されるので実際に はもっと大きな乱流消散エネルギーとなるわけで，この Eq. (3) の微分信号からの測定方法が異常に低い值を提 供しているわけでないことが言える.

熱線プローブの方向を水平にし，平均主流方向に設置 して測定した結果, 吐出流域で乱流強度が鉛直のプロー ブに比べ約 1.5 倍大きくなり，乱流消散エネルギーは約 2 倍になった. これは主流べクトルの方向変動が乱流と して測定されたことによって現れたものであるが，変動 值が大きくなるにしたがい信号のアナログ処理の誤差も 大きくなるし，また主流べクトル方向変動のため熱線プ ローブの余弦法則からのずれが無視できなくなるので, いずれにしても水平方向のプローブ設置は好ましくな W.

\section{$3 \cdot 2$ エネルギー収支に対する考察}

攪拌槽内に打いて, Fig. 8 に示すような半径 $r_{d}$ の仮 想円筒を考え ${ }^{\natural)}$ ，この円筒と槽壁に囲まれた二重円筒部 について，次のような仮定のもとにエネルギー流束およ び運動量流束の収支を求め, 考察を加える.

（1）槽内流は軸対称であり，また $z$ 方向流は水平流 に比べ無視できる.

（2）二重円筒部を吐出流部 $(U>0)$ と，その上下の 部分 $(U<0)$ に分け, 吐出流部上下は, 擬ポテンシャル 流で, 速度分布については $\bar{W}=\omega r_{c}{ }^{1.8} / r^{0.8}, r_{c} / r_{d}=0.77$ が成立している ${ }^{11)}$ もとする，またこの領域では変動成 分は平均流に比べ無視できないとする.

(3) 吐出流は摫汼翼周期に同調して周期的に大きく 変動しており，乙かも Günkel ら゙が示したように半径 方向成分と円周方向成分が同位相で変動しているものと
する。

（4）運動量保存則より摫拌翼から与えられる角運動 量はすべて槽壁の剪断力と釣り合っている．しかし底面 の剪断力は側面に比べ無視できるとする ${ }^{6)}$.

1) 運動量釣り合いの方程式 円筒座標でナビェ・ ストークスの方程式を変形すれば，仮想円筒部で以下の 運動量釣り合の式が導かれる゙ .

$$
\begin{gathered}
\rho \int_{0}^{H} 2 \pi\left(r^{2} U \bar{W}\right)_{r_{D}} d z+\rho \int_{0}^{H} 2 \pi\left(r^{2} \overline{U^{\prime} W^{\prime}}\right)_{r_{d}} d z \\
=\int_{0}^{H} 2 \pi\left(r^{2} \tau\right)_{r_{D}} d z=T
\end{gathered}
$$

仮定 (3) より吐出流の半径方向成分と周方向成分の相 関は大きく Eq. (5) の左辺第 2 項は無視できない.

そこで Eq. (5) の左辺全体を吐出流部とその他の擬ポ テンシャル流域に分けて考えると,

$$
\begin{aligned}
& \rho \int_{U>0} 2 \pi r_{d}^{2} W_{0} \bar{U}_{0} d z+\rho \int_{U<0} 2 \pi r_{d}^{2} W_{1} \bar{U}_{1} d z \\
& \quad+\rho \int 2 \pi r_{d}^{2}\left(\overline{W^{\prime} U^{\prime}}\right) d z=T
\end{aligned}
$$

ここで仮定 (2) に従い擬ポテンシャル域での変動成分は 小さいので運動量収支への寄与は無視した。

次に仮想円筒部の流量収支より次式を得る.

$$
\int_{U>0} 2 \pi r_{d} \bar{U}_{0} d z=-\int_{U<0} 2 \pi r_{d} \bar{U}_{1} d z=Q
$$

また Eq. (6) の左辺第 3 項に含まれる $W^{\prime}, U^{\prime}$ は同位 相で変動しているので

$$
\overline{\left(W^{\prime} U^{\prime}\right)_{r_{d}}}=\sqrt{\overline{W^{\prime 2}}} \sqrt{\overline{U^{\prime 2}}}=\beta^{2} \bar{W}_{0} \bar{U}_{0}
$$

と沶くことができる.ここで $\beta$ は乱れの強さの定義式と 同形であるが, 仮定 (3) で述べたよらに周期性があり, 乱 流の特性とは異なるので, ここでは主流の変動強度とい らように意味づけされるものである。そこで Eqs. (7)， （8）を Eq. (6) に代入すれば, 運動量の釣り合式は次の ように整理される. 


$$
(\alpha-\gamma)+\alpha \beta^{2}=\frac{P}{\rho W_{t}^{2} Q}
$$

ここで, $\alpha=W_{0} / W_{t}, \gamma=W_{1} / W_{t}$ で, 左辺第 1 項は主流 そのものに運ばれる角運動量から生じた項であり, 第 2 項は主流变動によって運ばれる角運動量から生じた項で ある。

2）堮出流周方向成分の平均速度および変動強度 Eq. (9) において右辺は動力数 $N_{P}$ と吐出流数 $N_{q d}$ の 定義を用いると，次の值となる.

$$
\frac{P}{\rho W_{t}^{2} Q}=\frac{N_{P}}{\pi^{2} N_{q d}}=0.297
$$

ただし永田らに従い $N_{P} / N_{q d}=2.95$ とした， $\gamma$ は翼先端 周速度に対する擬ポテンシャル域の周速度の比で仮定 （2）より 0.625 となる．また吐出流変動による運動量輸 送がない極限では $\beta=0$ で, 一方 $W_{0}>W_{1}$ であるか ら， $\alpha$ は次の範囲となる.

$$
0.923>\alpha>0.625
$$

すなわち，吐出流の周方向成分は翼先端速度の 0.65 倍 から 0.923 倍になくてはならない。この簌囲の中間值は $\alpha=0.75$ で，これは山本ら ${ }^{11)}$ の測定值に近い值である.

この值から逆算すると $\beta^{2}=0.23$ となる。

以上の $\alpha, \beta, \gamma$ の値から Eq. (9) の左辺第 1 項に対す る第 2 項の比を計算すると 1.38 となり, 主流変動によ って生ずる応力が運ぶ角運動量は主流そのものが運ぶ角 運動量流束以上であることを示している.

次に, 吐出流の周方向成分は Eq. (11) の範囲で単振 動的変動をしているものとすると, $\sqrt{\overline{W^{\prime 2}}} / W_{0} \fallingdotseq 0.1$ と なりここれは，Fig. 2 に示した方向に插入した熱線で測 定された乱流強度とも一致した。

3) 吐出流の半径方向成分の速度変動 まず翼の先 端速度に 対する吐出流の 半径方向成分の 平均速度の比 $\bar{U}_{0} / W_{t}$ は, 次のように求まる.

$$
\frac{\bar{U}_{0}}{W_{t}}=\frac{Q / \pi \cdot d \cdot b}{\pi n d}=\frac{N_{q d} \cdot n d^{3}}{\pi n d^{2} b}=\frac{N_{q d}}{\pi^{2}} \cdot \frac{d}{b} \fallingdotseq 0.1
$$

ただし $N_{P} / N_{q d}=2.95, N_{P}=0.59$ とし，また実験に用い た翼より $d / b=5$ とした. 一方, 周方向成分の変動強さ も前述のごとく，ほぼ 0.1 であるから $\sqrt{W^{\prime 2}} / W_{0}=0.1$, $\sigma_{0} / W_{t}=0.1$ Eq. (8) に代入することにより次の関係 が成立する.

$$
\sqrt{U^{\prime 2}}=\beta^{2} W \frac{\beta^{2}}{\alpha} W_{0}
$$

ここで, 前述と同様 $\alpha=0.75$ とすれば $\beta^{2}=0.23, \sqrt{U^{\prime 2}}$ $=0.23 W_{t}=2.3 U_{0}$ となり, 吐出流の半径方向変動流は半 径方向平均流より大きく, また $\sqrt{U^{\prime 2}}=0.3 / W_{0}$ となるの で，周方向平均流の約 3 割もあることになる。これは Fig. 4 で示した可視化実験で, 吐出流の流跡線の重社合 わせが大きく扇形に広がっていることと一致する。
4) 仮定円筒面のエネルギー速束 Fig. 8 の流束で 斜線をほどこした二重円筒部に流出入するエネルギーの 差引 $E_{d}$ は $r=r_{d}$ の仮想円筒面上のエネルギー流束の積 分であるので，次式で表される。

$$
E_{d}=\int_{0}^{H} \overline{\left\{P_{z}+(1 / 2) \rho\left(W^{2}+U^{2}\right)\right\} U} 2 \pi r d z
$$

ここに $P_{z}$ は流体の静圧である. また仮想円筒面の半径 方向の運動量流束密度 $P_{z}+\rho U^{2}$ は重力による水圧に等 しいと怙けば次式が成立する (Appendix).

$$
\left(P_{z}+\rho U^{2}\right)_{r d}=\rho g\left(H_{r d}-z\right)
$$

ただし $z$ の原点は槽底とした。

これを Eq. (12) に代入し，さらに摡拌翼が槽中心に あれば二重円筒部に流出入する位置エネルギーは相殺さ れることを考慮すれば次式を得る。

$$
E_{d}=\int_{0}^{H} \frac{1}{2} \overline{\rho\left(W^{2}-U^{2}\right) U} 2 \pi r d z
$$

ここで $W=\bar{W}+W^{\prime}, U=\bar{U}+U^{\prime}$ を代入し, Fig. 8 に 示した速度分布に従い, 吐出部と翼上下のポテンシャル に分けて積分するが，ポテンシャル部の変動項は小さい ので無視するとともに，吐出流部の変動項は同位相で変 していると考えると，Eq. (14) は次式となる.

$$
\begin{aligned}
E_{d}= & \frac{1}{2}\left(\bar{W}_{0}^{2}-\bar{W}_{1}^{2}\right) Q-\frac{1}{2} \rho\left(U_{0}^{2}-U_{1}^{2}\right) Q \\
& +\frac{1}{2} \rho\left(\bar{W}^{\prime 2}-3 \bar{U}^{\prime 2}\right) Q \\
& +\int_{U>0} \rho \bar{W}_{0} \bar{W}^{\prime} U^{\prime} 2 \pi r d z
\end{aligned}
$$

ここで右辺の第 $1,2,3$ 項は主流そのものによって運ばれ るェネルギーであり, 第 4 項は主流変動によって生じた 応力によるェネルギー流束である。

前述の考察より $\bar{W}^{\prime 2} \ll \bar{W}_{0}^{2}, \bar{U}_{0}^{2} \ll \bar{W}_{0}^{2}$ であるから, こ れらの項は無視されるすのとし,さらに $\alpha, \beta, \gamma を$ 用いて 上式を整理すれば

$$
E_{d}=\left\{\frac{1}{2}\left(\alpha^{2}-\gamma^{2}\right)-\frac{3}{2} \beta^{4}+\alpha^{2} \beta^{2}\right\} \rho W_{t}^{2} Q
$$

となる. Eq. (10) の值を用いると $\rho W_{t}^{2} Q=3.34 P$ とな り,さらに前述の考察より $\alpha=0.75, \beta^{2}=0.23, \gamma=0.625$ を代入すれば， $E_{d}=0.43 P$ となる。これは供給された軸 動力のうち約 4 割が二重円筒内で消費されることを示し ている。 また翼上下の固体的回転部では, エネルギーの 乱流消散は小さいと考えられるので, 所要動力の約 4 割 しか翼外で消散しないことになる。このため山本ら ${ }^{12) か ゙ ~}$ 指摘しているように軸動力の多くが翼内で消費されてい るるのと思われる。

Eq. (16) の第 1 項に対する第 2 項の比をとると約 0.9 となる。これは吐出部で低下した静圧が二重円筒部で回 復するに要したエネルギーが主流そのものの運動エネル ギー流束とほとんど同程度であることを示しており，第 


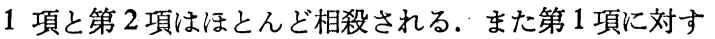
る第 3 項の比は 1.5 で, 主流変動によって生ずる応力が 運ぶェネルギーは主流の運動エネルギー流束の約 1.5 倍 もある. 第 1 項と第 2 項は主流そのもののエネルギー流 束であるが，互いに相殺され，結局翼外に運び出される 軸動力は主流の変動成分によるエネルギー流束に一致す る.

\section{5) 攪拌槽内壁での粘性消散 攪拌槽壁に形成され} る境界層で生ずる剪断力は一定として， $\tau=\tau_{w}$ とすると Eq. (5) より次式を得る

$$
\frac{\pi D^{2}}{2} H \cdot \tau_{w}=T
$$

一方，境界層の粘性消散 $E_{\mu}$ は次式で表される.

$$
E_{\mu}=\mu\left(\frac{\partial W}{\partial r}\right)_{r D}^{2} \delta \pi D H
$$

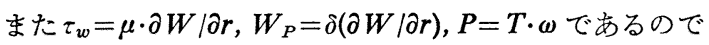

$$
E_{\mu}=\tau_{w} W_{D} \cdot \pi D H=\frac{W_{D}}{(1 / 2) \cdot D \omega} P
$$

ここで再び仮定 (2) の速度分布を用いると， $E_{\mu}=0.18 P$ となる．よって境界層では所要動力の約 $18 \%$ が消費さ れていることになる.

以上の考察により翼外のバルク液全体で乱流消散され るエネルギーEは翼上下の固体的回転部を無視すれば, $E=E_{d}-E_{\mu}=0.43 P-0.18 P=0.25 P$ となり, 所要動力の 約 $25 \%$ しか消散されない.これは著者らの実験結果と ほとんど同じ值である。

\section{結呾}

邪魔板なし攪拌槽内の乱流消散エネルギーを熱線流速 計で測定し, 測定法の検討と測定された消散エネルギー と所要動力との関係を運動方程式と既往の速度分布実験 式を用いて導いたエネルギー収支から半理論的に検討し 次の結果を得た。

槽内流れはほとんど水平面に平行であり，水用プロ一 ブは余弦法則からのずれが大きいことを考慮すれば，熱 線プローブは鉛直に押入する方が好ましい。

従来からよく行われるエネルギースペクトルより求め る消散エネルギー算出法は, 消散エネルギーに寄与する 高周波側スペクトルを低周波側から外挿するため, 非等 方性の強い挸拌槽内乱流では適当でない.

測定された消散エネルギーは吐出流部で強く, 槽内位 固による差異が最大数十倍に達するが, 各位置での消散 エネルギーは所要動力に比例し, 分布形状は回転数によ らない, またバルク液内乱流消散エネルギーは所要動力 の約 2 割弱にしかならない.

これに関して吐出流部の主流ベクトル変動による運動 量流束を考慮し運動方程式と, 既往の速度分布実験式か
ら所要動力と消散エネルギーの関係を求めると実験值と よい一致をし, 運動方程式からもバルク内乱流消散エネ ルギーは所要動力の一部しか消費していないことを示 した.

槽壁面に形成される境界層内の粘性消散エネルギーを 計算するとバルク液内乱流消散エネルギーと同程度であ る.

\section{Appendix}

3.2 の仮定 (1) で示したように, 軸対称流, 上下流無 視, 定常流と仮定することにより, Navier-Stokes 方程式 と連続の式より半径方向運動量釣合は次式で示される.

$$
\frac{\partial r}{\partial\left(P_{z}+\rho U^{2}\right)}=\rho \frac{W^{2}-U^{2}}{r}
$$

これを仮想円筒面 $r_{d}$ から槽壁 $r_{D}$ まで積分し，槽壁で は， $U_{r_{D}}=0$ であることを考虑すれば次式となる。

$$
\left(P_{z}+\rho U^{2}\right)_{r_{d}}=\left(P_{z}\right)_{r_{D}}-\rho \int_{r_{d}}^{r_{D}} \frac{r}{W^{2}-U^{2}} d r
$$

左辺 $\left(P_{z}+\rho U^{2}\right)_{r_{d}}$ は仮想円䉍面の運動量流速密度であ り, 右辺の $\left(P_{z}\right)_{r_{D}}$ は壁面の圧力で, 槽壁での水面高さを $H_{r_{D}}$ とすると $\rho q\left(H_{r_{D}}-z\right)$ に等しい. また右辺第 2 項 は，遠心力の積分から $\rho \int U^{2} / r \cdot d r$ を差引いたもので, 凝ポテンシャル域では $U$ は無視されるため遠心力の積 分だけとなり，水面上昇に等しくなる。また吐出流部で は $U$ は無視できないが, $W$ も凝ポテンシャル部より大 きいため, $\int\left(W^{2}-U^{2}\right) / r \cdot d r$ は凝ポテンシャル部の值と ほとんど同じと仮定すると，この項は槽壁と仮想円筒面 の水位差を表していることになり，次式が成立する。

$$
\rho g H_{r_{D}}=\rho g H_{r_{d}}+\rho \int_{r_{d}}^{r_{D}} \frac{W^{2}-U^{2}}{r} d r
$$

Eq. $(A-3)$ の関係と $\left(P_{z}\right)_{r_{D}}=\rho q\left(H_{r_{D}}-z\right)$ を $(\mathrm{A}-2)$ に適 用すると， $\left(P_{z}+\rho U^{2}\right)_{r d}=\rho q\left(H_{r d}-z\right)$ を得る.

\section{Nomenclature}

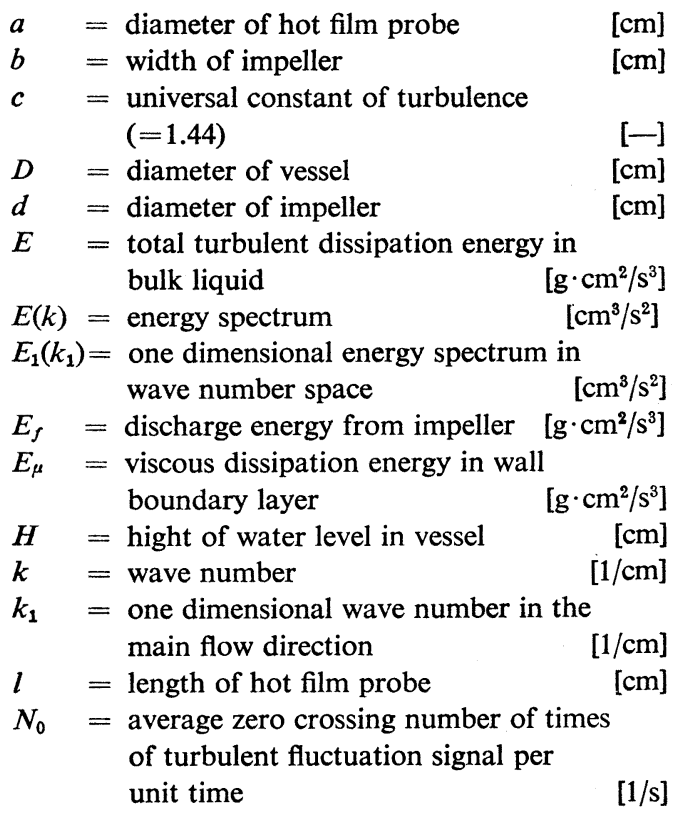




\begin{tabular}{|c|c|c|c|c|}
\hline$N_{P}$ & $=$ & power number & $\bar{\lambda}_{f}$ & $=$ longitudinal dissipation scale \\
\hline$N_{q d}$ & $=$ & discharge flow number & $\mu$ & $=$ viscosity of liquid \\
\hline$n$ & $=$ & rotational speed & $\nu$ & $=$ kinetic viscosity of liquid \\
\hline$P$ & $=$ & power input & $\rho$ & $=$ density of liquid \\
\hline$P_{s}$ & $=$ & static pressure & $\tau$ & $=$ tangential shear stress \\
\hline$P_{v}$ & $=$ & power input per unit mass & $\tau_{w}$ & $=$ shear stress at wall \\
\hline$Q$ & & discharge flow rate & $\langle\mathrm{Su}$ & bscripts $>$ \\
\hline $\operatorname{Re}$ & $=$ & Reynolds number for agitation & 1 & $=$ value at radius $r_{d}$ in pseudo potential \\
\hline $\operatorname{Re}_{2}$ & $=$ & turbulent Reynolds number $\left(=u^{\prime} \lambda_{f} / \nu\right) \quad[-]$ & & region \\
\hline$r$ & $=$ & radial distance & 0 & $=$ value at radius $r_{d}$ in discharged flow \\
\hline$r_{c}$ & $=$ & radius of forced vortex & $\langle\mathrm{Su}$ & perscripts $>$ \\
\hline$r_{d}$ & $=$ & radius of impeller & - & $=$ time average \\
\hline$r_{D}$ & $=$ & radius of vessel & ' & $=$ oscillating velocity of the discharged flow \\
\hline$T$ & $=$ & {$\left[\mathrm{g} \cdot \mathrm{cm}^{2} / \mathrm{s}^{2}\right]$} & & \\
\hline$t$ & $=$ & time & & Literature cited \\
\hline$U$ & $=$ & velocity in radial direction & & \\
\hline$u$ & $=$ & turbulent fluctuation & 1) & $\begin{array}{l}\text { Champage, F. H., C. A. Sleicher and O. H. Wenrmann: } \\
\text { J. Chem. Eng. Japan, 28, } 153 \text { (1967) }\end{array}$ \\
\hline$u^{\prime}$ & $=$ & root mean square of turbulent & 2) & Cutter, L. A.: AIChE J., 12, 35 (1966) \\
\hline & & $\left(u^{\prime}=\sqrt{ } \overline{u^{2}}\right)$ & 3) & GunkelA. A. and M. E. Wever: AIChE J., 21, 931 (1975) \\
\hline$W$ & $=$ & velocity in tangential direction & 4) & Hinze, J. O.: “Turbulence” McGraw-Hill Comp. (1975) \\
\hline$W_{D}$ & & velocity in tangential direction at the & 5) & $\begin{array}{l}\text { Hiraoka S. and R. Ito: J. Chem. Eng. Japan, 8, } 323 \\
\text { (1975) }\end{array}$ \\
\hline$W_{t}$ & $=$ & $\begin{array}{l}\text { vessel wall } \\
\text { tip velocity of the impeller }\end{array}$ & 6) & $\begin{array}{l}\text { Mizushina, T., R. Ito, S. Hiraoka and K. Fujimoto: } \\
\text { Kagaku Kögaku, 37, } 409 \text { (1975) }\end{array}$ \\
\hline$x$ & & $\begin{array}{l}\text { distance along the main flow } \\
\text { direction }\end{array}$ & 7) & $\begin{array}{l}\text { Mujumdar, A. S., B. Huang, D. Wolf, M. E. Weber and } \\
\text { W. J. M. Douglas: The Canadian J. Chem. Eng., 48, } 475 \\
\text { (1970) }\end{array}$ \\
\hline$z$ & $=$ & axial distance & 8) & $\begin{array}{l}\text { Nagata, S., Y. Yamamoto, K. Hashimoto and Y. Naruse: } \\
\text { Kagaku Kögaku, 23, } 595 \text { (1959) }\end{array}$ \\
\hline$\alpha$ & & $W_{0} / W_{t}$ & 9) & $\begin{array}{l}\text { Okamoto, Y., M. Nishikawa and K. Hashimoto: Kagaku } \\
\text { Kogaku Ronbunshu, 5, } 410 \text { (1979) }\end{array}$ \\
\hline$\beta$ & & $\begin{array}{l}\text { defined by Equation } 8 \text { (measure of } \\
\text { discharge flow fluctuation) }\end{array}$ & 10) & $\begin{array}{l}\text { Sato, Y., M. Kamiwano and K. Yamamoto: Kagaku } \\
\text { Kögaku, 34, } 104 \text { (1970) }\end{array}$ \\
\hline $\begin{array}{l}\gamma \\
\varepsilon\end{array}$ & $=$ & $W_{1} / W_{t}$ & 11) & Yamamoto, K.: Dr. Thesis, Kyoto Univ. Kyoto Japan \\
\hline$\varepsilon$ & & turbulent dissipation energy & & (1960) \\
\hline$\varepsilon^{\prime}$ & & $\begin{array}{l}\text { turbulent dissipation energy calculated } \\
\text { from energy spectrum } \quad\left[\mathrm{cm}^{2} / \mathrm{s}^{3}\right]\end{array}$ & 12) & $\begin{array}{l}\text { Yamamoto, K. and S. Nagata: Kagaku Kögaku, 26, } 510 \\
\text { (1962) }\end{array}$ \\
\hline$\theta$ & $=$ & azimuthal angle & & (1980 年 9 月 3 日受理) \\
\hline
\end{tabular}

\title{
Relation between Power Input and Turbulent Dissipation Energy in Non-Baffled Agitated Vessel
}

\author{
Shigeki Toyama, Takaaki Ameno and Morio Sogame \\ Dept. of Chem. Eng., Nagoya Univ., Nagoya 464
}

The turbulent dissipation energy was measured in a non-baffled agitated vessel with a hot-film anemometer.

The energy calculation was subjected to the differentiated signal of turbulent fluctuation rather than to conventional energy spectrum method, because the former provided better results than the latter according to our investigation. The results also indicated that vertical insertion of hot film probe was better than horizontal.

The trubulent dissipation energy depends largely on location, and its values were expanded over the range of several multiples of ten. The value at each location was proportional to power input, and there was little change in shape of the contour map. The integrated amount of this energy over the bulk liquid was only below $20 \%$ of the actual power input.

This result was verified by energy balance derived from the momentum equation considering the main flow vector fluctuation in the discharge flow region.

The amount of viscous dissipation energy in the boundary layer on the vessel wall was also calculated from the above equation and this was almost the same as that of turbulent dissipation energy in the bulk liquid. 